\title{
CASES OF INTEREST
}

\section{A CASE OF EAGLE-BARRETT (PRUNE-BELLY) SYNDROME}

The "Prune-Belly" syndrome is a rare complex of congenital malformations consisting of absence of the anterior abdominal muscles, obstructive uropathy and bilateral cryptorchidism. Because of the consistency with which these three features occur it is often referred to as the Triad Syndrome.

The syndrome occurs in 1 in 50,000 live births and over 200 cases have now been reported in the world literature. Ninety five per cent of patients are male and can be affected with varying degrees of severity.

It was first recognised by Fröhlich in 1839. He described the misshapen abdomen but it was not until 1895 that the triad of malformations was described by Parker. Osler in 1901 first likened the appearance of the abdomen to that of a prune. By 1934 a total of 33 cases had been reported and in 1950 Eagle and Barrett gave their names to the syndrome when they reviewed nine of their own cases at the Babies' Hospital, New York.

A single case in a set of twins is described here.

Baby $\mathbf{P}$ was the second of twins born after spontaneous labour at 36 weeks gestation in a previous uneventful pregnancy. His twin brother was normal apart from an absent finger-nail and bilateral "clicking" hips. There was no family history of congenital abnormality and the parents had one normal child from a pregnancy 3 years previously.

The umbilical cord was friable and oval on section rather than round. It contained three vessels and was inserted at the edge of an uniovular placenta. The infant had the typical appearance of the syndrome with a lax wrinkled abdomen and flaring of the inferior costal margin (Fig. 1). The bladder and the left ureter were grossly dilated and could be easily seen through the soft abdominal covering.

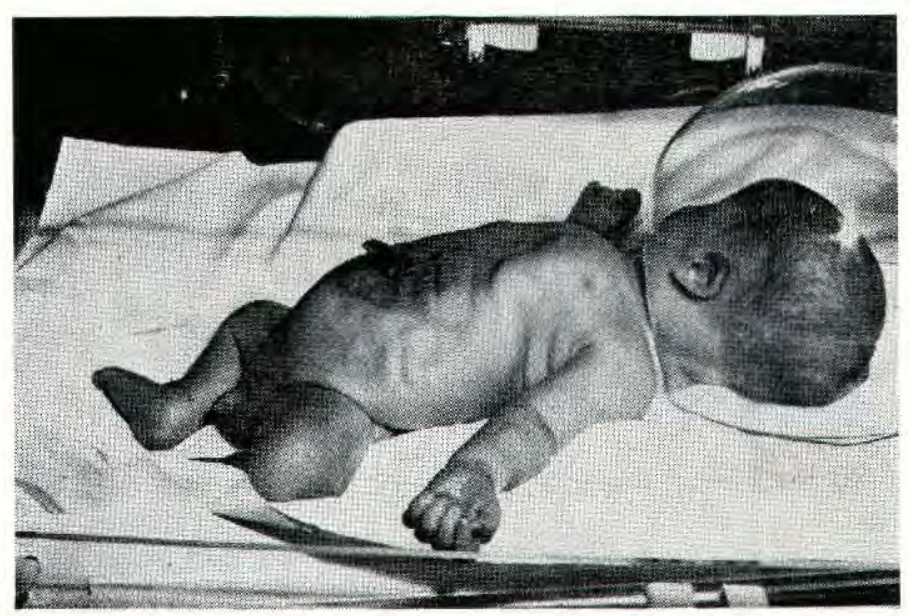

Fig. 1. Prune-belly syndrome 
The urachus was patent and both testes were undescended. There was complete urinary outflow obstruction and even the smallest catheter could not be passed into the atretic urethra.

There were several other abnormalities which are not invariably present with this syndrome but have been reported. These were flaccid lower limbs, patulous anus and unilateral talipes equino-varus, all suggestive of myelodysplasia but without any evidence of spinal dysraphism. There was also severe thoraco-lumbar scoliosis, impaired perfusion of the right leg causing persistent cyanosis of the limb, and abnormal ears with absence of normal cartilage. The incidence of each particular abnormality in reported cases is shown in Table I.

Table I

The incidence of each particular abnormality in reported cases of Eagle-Barrett syndrome

\begin{tabular}{|l|c|}
\hline \multicolumn{1}{|c|}{ Abnormality } & $\begin{array}{c}\text { Percentage incidence in } \\
\text { reported cases }\end{array}$ \\
\hline Deficiency of anterior abdominal muscles & 100 \\
\hline Undescended testes & 96 \\
\hline Megacystis and megaureter & 93 \\
\hline Flaring of inferior costal margin & 75 \\
\hline Talipes equino-varus & 70 \\
\hline Urethal atresia & 7 \\
\hline Patent urachus & 4 \\
\hline Thoraco-lumbar scoliosis & Not known \\
\hline Myelodysplasia & Not known \\
\hline Abnormal ears & Not known \\
\hline Inadequate circulation of lower limbs & Very rare \\
\hline
\end{tabular}

An intravenous pyelogram showed no concentration or excretion of contrast medium and the creatinine clearance was less than $1 \mathrm{ml} / \mathrm{min}$. However large quantities of dilute urine were produced and drained from the bladder by intermittent needle aspiration. Definitive surgery to relieve the urinary obstruction was not considered feasible because of the negligible renal function and despite adequate bladder drainage the infant died of renal failure on the 7 th day.

\section{Post mortem findings}

The anterior abdominal muscles were absent except for a small slip of muscle on each side of the midline below the xiphisternum. Both kidneys were grossly hypoplastic, each being less than $1 \mathrm{~cm}$ in diameter and irregularly shaped. The left ureter was dilated and tortuous. The right ureter was narrow and atretic. The bladder was grossly dilated and was attached to the umbilicus by a patent urachus. Both testes were found in the abdomen and were normal on section. The urethra was atretic and no prostatic tissue was found. 
The findings were consistent with the severest form of the syndrome (grade 4) according to Welch and Kearney (1974) who graded the syndrome according to severity in order to develop a rational approach to treatment based on the degree and type of genito-urinary tract involvement (Table II).

The object of treatment is to relieve urinary obstruction and protect the kidneys from pressure atrophy, infection and reflux.

Table II

Approach to treatment based on the degree and type of genito-urinary tract involvement

\begin{tabular}{|c|c|c|c|c|}
\hline Grade & 1 (Mild) & 2 (Moderate) & 3 (Severe) & 4 (Hopeless) \\
\hline Bladder & Small & $\begin{array}{l}\text { Mild } \\
\text { megacystis }\end{array}$ & Megacystis & Megacystis \\
\hline Uretha & Narrow & Narrow & Narrow & Atretic \\
\hline Ureters & Normal & $\begin{array}{l}\text { Moderate } \\
\text { megaureter }\end{array}$ & $\begin{array}{l}\text { Severe } \\
\text { megaureter }\end{array}$ & $\begin{array}{l}\text { Severe } \\
\text { megaureter }\end{array}$ \\
\hline Ureteric reflux & Absent & Moderate & Severe & Severe \\
\hline Kidneys & $\begin{array}{l}\text { Unilateral } \\
\text { dysplasia }\end{array}$ & $\begin{array}{l}\text { Unilateral } \\
\text { dysplasia }\end{array}$ & $\begin{array}{l}\text { Unilateral } \\
\text { dysplasia }\end{array}$ & No function \\
\hline TREATMENT & 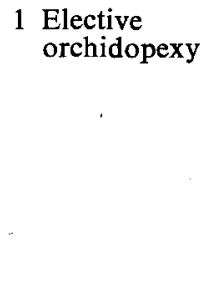 & $1 \begin{array}{l}\text { Repair of } \\
\text { patent } \\
\text { urachus } \\
2 \text { Ureteric } \\
\text { reimplant }\end{array}$ & $\begin{array}{l}12 \text { Ureterostomies } \\
2 \text { Renal } \\
\text { biopsies } \\
3 \text { Ureteric } \\
\text { reconstruction } \\
\text { with protect- } \\
\text { ive tube } \\
\text { nephrostomy } \\
\text { at } 6 \text { to } 9 \\
\text { months }\end{array}$ & $\begin{array}{l}1 \text { Palliative } \\
\text { high urinary } \\
\text { diversion }\end{array}$ \\
\hline
\end{tabular}

\section{Aetiology}

There is no substantial evidence for an environmental cause or chromosomal abnormality. Indeed, there has been a notable lack of affected siblings in the 200 or so cases already described. There have been only 4 reports of affected male siblings and 2 reports of affected cousins.

Chromosome studies, when carried out, have, with only 2 exceptions, been normal. One was clinically and by Karyotype a trisomy 18 and two male siblings were reported to be mosaic for monosomy 16. Chromosomal abberation may be the aetiology for a very few cases but the vast majority appear to occur sporadically with no genetic component.

\section{Pathogenesis}

It was originally thought that the abdominal muscle deficiency occurred because of constant pressure from a dilated urinary tract (Stumme 1903) and it was later proposed that the uropathy occurred because of laxity of the abdominal wall (Ikeda and Stoesser 1927). It is difficult to support such theories as numerous cases 
of obstructive uropathy and other congenital abdominal swellings occur without atrophy of the abdominal muscles and, conversely, exomphalos and gastroschisis, conditions associated with defects of the anterior abdominal musclulature, are often accompanied by a normal genito-urinary system.

\section{Embryology}

A defect of mesodermal development before the end of the third week of embryonic life has been suggested as a convenient explanation for the syndrome (Ives 1974). At the onset of the third week the ectodermal primitive streak is formed and the initial outpouring of mesoderm is taking place. The mesoderm has not yet achieved a bilateral distribution and it is at this point in development that the defect in the mesoderm is postulated. The mesoderm separates during the third week to form the paraxial mesoderm, intermediate mesoderm and the lateral plate mesoderm. Paraxial mesoderm forms the somites and deficiency would account for the abdominal wall defect. The intermediate mesoderm gives rise to the kidneys and ureters so an early defect would cause renal dysplasia. The lateral mesoderm forms the musculature of the bladder and ureters and the gubernaculum. Hence the megacystis, megaureter and undescended testes following a defect in lateral plate development.

There have been a few syndromes reported in which the abnormalities were unilateral. Presumably the defect in mesodermal development occurred in a later stage in these cases after it had achieved a bilateral distribution.

\section{Increased incidence of twins}

There is a significantly increased incidence of monozygotic twins in this syndrome. One in 23 is a twin compared to 1 in 80 in the general population.

Monozygotic twins are thought to have their origin at the beginning of the third week of embryological development with splitting of the embryonic disc at the time of primitive streak formation. Unequal division of mesodermal cells may cause a deficiency in one twin with subsequent development of the prune-belly syndrome. This increased incidence of twinning would tend to support Ive's (1974) theory of the embryogenesis of the syndrome.

\section{Acknowhledgements}

My thanks are due to Lieutenant-Colonel J. G. Holmes-Smith, R.A.M.C. for his advice and encouragment during preparation of this article and to Colonel J. C. Wilson, Late R.A.M.C. for permission to report on his patient.

\section{CAPTAIN C. H. OLIVER}

\section{REFERENCES}

EAGLE, F. J. and BARrett, G. S. (1950) Paediatrics 6, 721

FroHLICH, F. (1839). Wurzburg C. A., Zum

IKEDA, K. and Stoesser, A. V. (1927). Amer. J. Dis. Child. 33, 286

IVES, E. J. (1974) Birth Defects. Original Article Series. Vol. X. No. 4

OSLER, W. (1901). Bull. Johns Hopk. Hosp. 12, 331

PARKer, R. W. (1895). Lancet i, 1252

Stumme, E. G. (1903) Mitt. Grenzgeb. Med. Chir. 11, 548

WELCH, K. J. and KeARNEY, G. P. (1974) J.Urol, (Baltimore) 111, 693 